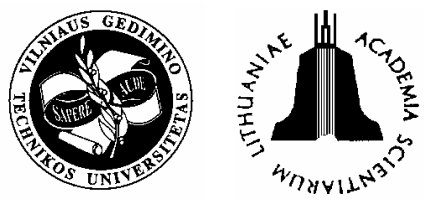

\title{
ANALYSIS OF BEHAVIOUR OF CONTACT BETWEEN THE PROFILED STEEL SHEETING AND THE CONCRETE
}

\author{
Juozas Valivonis \\ Dept of Reinforced Concrete and Masonry Structures, Vilnius Gediminas Technical University, \\ Sauletekio al.11, LT-10223 Vilnius.E-mail: gelz@st.vtu.lt
}

Received 20 Jan 2006; accepted 12 May 2006

\begin{abstract}
In designing composite structures it is necessary to verify the following three sections: normal, diagonal and horizontal. The behaviour of composite steel-concrete structures with external profiled reinforcement is directly dependent on the deformability and contact strength. In contact behaviour between concrete and profiled steel sheeting three stages are distinguished: the first - until chemical bond is effective, the second - after failure of chemical bond, the third - after failure of mechanical bond when composite action is provided by friction and anchors. Deformability and contact strength is substantially influenced by the shape of the profiled sheeting, the pre-compressing force acting perpendicularly to a contact plane and the horizontal forces restraining transversal strains of concrete. It was established by investigations that a shear strength of contact between concrete and profiled steel sheeting increases and shear strain decreases with an increase of contact between concrete and sheeting pre-compressing forces and concrete transverse strain restraining forces.
\end{abstract}

Keywords: profiled steel sheeting, concrete, contact, strength, slip, failure.

\section{Introduction}

The behaviour of composite cast in situ steelconcrete floors, reinforced with profiled steel sheeting, is directly affected by strength of contact [1-7]. Nature of failure of composite slabs is determined by the strength of contact between profiled steel sheeting and concrete [8, 9]. Rigidity of contact between profiled sheeting and concrete is very important for an effective action of composite steel-concrete slabs [10-14]. Composite action of layers can be achieved by a reduction of slip between concrete and steel sheeting in the plane of contact [1518]. Contact strength and deformability is determined by: chemical steel and concrete bond, mechanical strength of contact, friction between concrete, steel and anchors [19, 20].

In the behaviour of contact between concrete and profiled sheeting of composite steel-concrete structures three stages are distinguished: the first - until chemical bond is effective, the second - after failure of chemical bond, the third - after failure of mechanical bond when friction and anchors provide a composite action.

Investigations carried out indicate that chemical bonds often fail before the service stage of the structure. The failure is caused by concrete shrinkage.

Effective action of contact can be improved by selecting suitable shapes of steel [21].

Holorib-type profile sheeting in use is provided with dovetail shape ribs. Transverse rib at the top of the main rib or adjacent concrete is subjected to local pressure when the contact deforms. Delamination (separation) is prevented by dovetail shape of rib, resulting in greater stiffness and strength of the contact.
At supports of composite steel-concrete structures forces due to support reactions develop. They give rise to compression in contact and the mechanical bond and friction for contact increases. Investigations of composite slabs [1] indicate that during failure of slabs in their support zone a longitudinal crack near longitudinal ribs of profiled sheeting occurs. The magnitude and character of the crack is defined by an amount and type of horizontals and perpendiculars to the rib reinforcement in concrete. This reinforcement restrains transversal strains of concrete. For determining the influence on contact strength of vertical pre-compression force, the magnitude and force restraining transverse strains, experimental investigations of strength and deformability of contact with profiled steel sheeting in composite steel-concrete slabs were performed.

\section{Stress and strain state in the contact zone}

Stresses and strains in the contact zone between the profiled metal sheeting and the concrete are complex, depending on many factors and not completely investigated. In many cases when sheeting ribs are with keys, the joint action of concrete and sheeting is similar to the behaviour of reinforcement of deformed bars and concrete. Researches conducted by scientists in many countries and by us indicate however that it is not completely investigated yet [22].

In the contact zone between the profiled sheeting and the concrete, in flexural members shear forces appear (Fig 1). In the plane of contact between the layers (between the keys) resistance to shear stress $\tau_{s}$ is provided by bond and friction. In the keys plane shear forces $T$ induce 
a compression stress $\sigma_{c}$ (local compression). Since the vertical plane of the keys is inclined to the shear force $T$, a vertical force $F_{v}$ appears which develops lifting action on the concrete above the keys (Fig 1 b). It means that because of the key at the contact a compression and local compression in the concrete along the rib length appear.
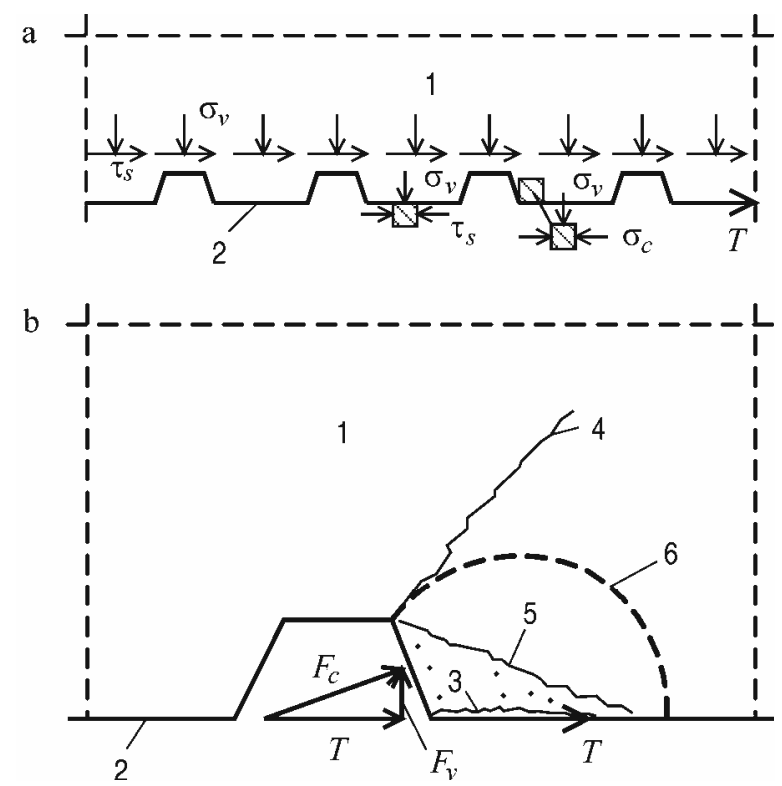

Fig 1. State of stresses and strains in the contact zone between the profiled sheeting and the concrete: a - distribution of stresses along the rib; $b$ - stresses and mechanism of failure at the key on the rib: 1 - concrete; 2 - rib in the sheeting; 3 - spalled-off concrete; 4 - crack due to the principal stresses; 5 - destruction of concrete inner structure, cracks; 6 - plasticity zone

From the general theory of mechanics of solids one knows that in local compression in transverse direction tensile strain develops:

$$
\varepsilon_{y}=\frac{1}{E_{C}}\left[\sigma_{C}-v\left(\sigma_{z}+\sigma_{v}\right)\right],
$$

here: $E_{c}$ - concrete elasticity modulus; $v$ - Poisson's ratio of the concrete; $\sigma_{z}$ - stress in the concrete transversal to the rib caused by the keys.

Since the keys depth and their total area subjected to the local compression is not large, therefore very large local compression stresses develop and at the same time great stresses in transverse direction are induced. A complex state of stresses emerges. Since the value of the principal tension stress exceeds the limit value of tension, resistance diagonal cracks at the keys appear:

$$
\sigma_{c . m . t}=\frac{\sigma_{v}+\sigma_{C}}{2}-\sqrt{\left(\frac{\sigma_{v}-\sigma_{C}}{2}\right)^{2}+\tau_{x y}^{2}}>f_{c t k} .
$$

However, in case of a small area subjected to local compression and great values of local compression stresses, diagonal cracks due to action of the principal stresses may not appear. Under such circumstances the internal bond and structure of concrete particles begin to break. An area of pressed out concrete emerges and its surface is described by the line 5 (Fig $1 \mathrm{~b}$ ). Consequently, concrete and the key transverse stresses increase with the shear. New cracks appear that in their depth and the height can cross the whole concrete layer. From the other side this concrete together with the key acts as a wedge which due to shear between concrete and sheeting facilitates to further increase in tensile stresses in transverse direction and splitting of the concrete in longitudinal direction of the shear force action. Due to development of these deformations and cracking, the keys loose their carrying capacity.

As it is shown in Fig 2, the concrete layer above the sheeting rib is torn off from the bottom layer. Tearing off begins at the upper corner of the rib; it is caused by the force $F_{v}$ (Fig 1) when tensile stress $\sigma_{c t}>f_{c t}$.

Appearance of diagonal cracks with all other conditions similar depends mainly on the height, width and spacing of the keys. These factors affect the displacement between the layers, ie the contact zone stiffness as well.

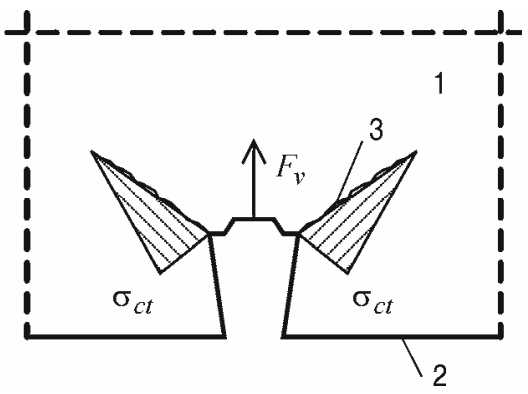

Fig 2. Distribution of load effects in transverse direction of the rib: 1 - concrete; 2 - sheeting; 3 - direction of the main crack

The analysis of stress state gives an opportunity to distinguish three main stages in the behaviour of contact zone between the profiled metal sheeting and the concrete:

- an elastic stage. The concrete is subjected to local compression and it can be considered present until $\sigma_{c, c} \cong f_{c k}$;

- plastic deformations development stage. As the stress of local compression $\sigma_{c, c}>f_{c k}$ in the concrete at the edge zone of the key, the inner bond begins to break and shear deformation between elements of the structure develop and in the meantime plastic zone occurs. This zone expands into the concrete increasingly with growth of the shear force. Development of this zone becomes more progressive or causes the appearance of cracks, slip between the layers increases;

- stage when the diagonal cracks appear or the concrete breaks off at the keys. Cracks can develop in places where stresses concentrate in the zone of the principal compression stresses in the direction of their trajectories. Their direction varies with the plasticity development.

When the depth of the keys is small, such cracking may be not substantial but the concrete broken by local compression together with the key making a wedge splits the concrete while plastic deformations developed from the pressure upwards reduces the concrete ability to resist 
the key slipping. Carrying capacity of the contact reduces. This indicates that there is a different relationship between shear force causing the corresponding state of stresses and the slip $u$ between the layers in different stages and different values as well. For a general case it can be described by the following function:

$$
u=f\left(\frac{\sigma_{c, c}}{f_{c}}, c, b, E_{c}, f_{c t}\right),
$$

where $c, b$-depth and width of the key.

By the investigations in behaviour of various anchors in the concrete was found that the basic parameter is $\frac{\sigma_{C, C}}{f_{C}}$ and then

$$
u=\beta\left(e^{0,5 \frac{\sigma_{c, c}}{f_{c k}}}-1\right),
$$

here $\beta$ - coefficient taking into account the influence of dimensions and shape of the key.

\section{Test specimens and method}

28 composite specimens of the same dimensions have been produced for investigations (Fig 3). They were of concrete and steel pieces of profiled sheeting. These pieces were cut from Holorib-2000 steel sheeting. In the centre of steel pieces for specimens there was a rib of variable width and of dovetail shape. Top of the rib was $2 \mathrm{~mm}$ high transverse ribs (Fig 3), which during their production form keys. An average concrete cube strength for specimens was $34 \mathrm{MPa}$. Crushed gravel and quartz sand was used for concrete. Specimens until testing were stored under laboratory conditions and tested at the age of 28 days.

Special arrangement was used for tests (Fig 4). During a testing a profiled steel sheeting was fixed in a testing bed. A hydraulic jack was used to apply testing forces. Force value was controlled by pressure monometer, and deformations - by mechanical dial gauges fixed in testing bed.

a

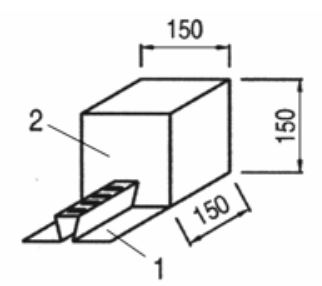

b

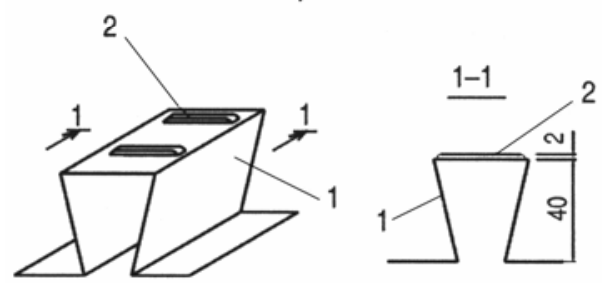

Fig 3. Structure of specimens: a - general view: 1 - profiled steel sheeting; 2 - concrete; b - rib in profiled steel sheeting: 1 - rib; 2 - transverse rib

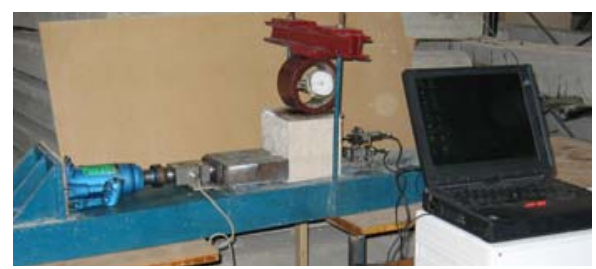

Fig 4. Overview of test set up

Shear force was increased in steps. Value of a step was $1 \mathrm{kN}$.

For determining the effect on contact strength of force acting perpendicularly to contact plane an arrangement in the testing bed was installed that enabled one to compress contact by the force perpendicular to contact plane. The force was applied mechanically stretching special ties.

\section{Contact strength and failure procedure}

7 series CA, CB, CD, CE, CF, CG ir CH of specimens were tested. Shear force applied to contact, compression force acting perpendicularly to concrete and steel sheeting interface and contact shear deformations were recorded during tests. Specimens CA were tested for shear force action only. Specimens CB, CD and CE were tested for action of shear forces and with pre-compression of contact surface by perpendicular forces. The precompression force was equal to $5 \mathrm{kN}$ for specimens $\mathrm{CB}$, $10 \mathrm{kN}$ - for specimens CD, $15 \mathrm{kN}$ - for specimens CE. Specimens CF, CG and CH were subjected to shear force action with pre-compression of steel sheeting and concrete contact by $10 \mathrm{kN}$ force and with restraining of strains perpendicularly to a profiled steel sheeting rib.

The value of a strain restraining force was equal to $1 \mathrm{kN}$ for CF specimens, $3 \mathrm{kN}$ - for CG specimens and $5 \mathrm{kN}$ - for $\mathrm{CH}$ specimens. Pre-compression and strain restraining forces during tests were constant.

In tests of other authors [19] with Hibond-type profiled steel sheeting it was possible to distinguish a loss of chemical bond between steel and concrete and a complete contact failure as well. Our tests revealed that there are complicated problems to record failure of chemical bonds when Holorib-type profiled steel sheeting is applied. In this case the chemical bond failure does not cause significant shear deformations. It is because of keys existing in the rib, which almost immediately take shear stresses.

The specimens failed due to deformation of keys and with concrete crushing due to local compression at keys, which was followed by concrete splitting.

It was determined by experiments that the shear strength of contact between steel profiled sheeting and concrete depends on the magnitude of pre-compression force $\left(F_{p c}\right)$. Tests showed that at the pre-compression force of $5 \mathrm{kN}$ (specimen $\mathrm{CB}$ ), which is equal to $0,26-0,28$ of not pre-compressed contact failure force $\left(F_{u 0}\right)$, had no effect on the contact strength. For both CA and CB specimens contact failure force was equal to $17-18 \mathrm{kN}$ (Fig 5). When $F_{p c}$ was increased more, then the contact failure force $\left(F_{u}\right)$ increased. An increase in contact shear 
strength was caused by activation of friction between concrete and steel and the effect of keys resistance.

It was obtained by tests that pre-compression of the contact by force of $10 \mathrm{kN}$ perpendicular to contact plane resulted in contact strength increase by $22-25 \%$ in comparison with that of non-precompressed contact (Fig 5). In this case $F_{p c} \cong(0,53 \div 0,55) F_{u 0}$.
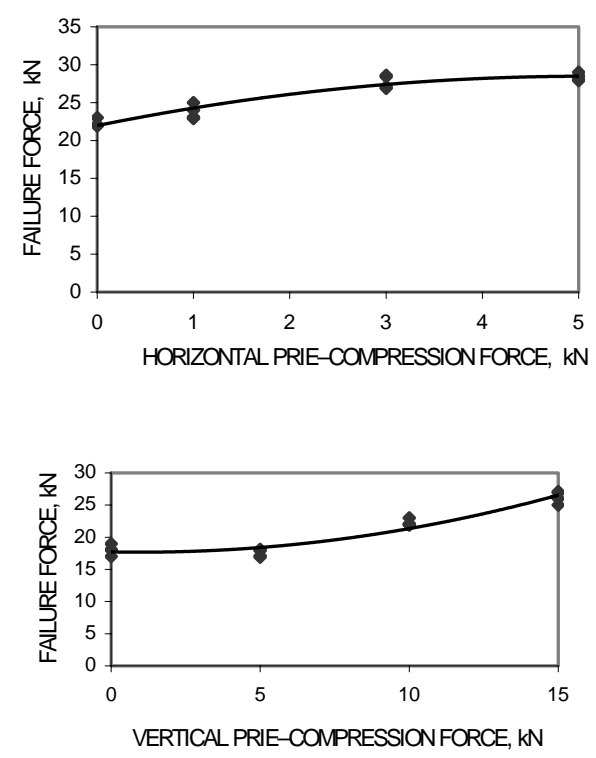

Fig 5. Influence of pre-compression on strength of contact between profiled steel sheeting and concrete

When contact was pre-compressed with perpendicular force of $15 \mathrm{kN}$, which was equal to $(0,39-0,83) F_{u 0}$, the contact strength increased by $50 \%$ in comparison with that of non-precompressed contact.

Investigations have indicated that a low precompression of steel sheeting and concrete contact (up to $30 \%$ of contact failure force) has no practical effect on contact strength. When pre-compression force is increased up to $\sim 0,8 F_{u 0}$, the contact strength increases up to $50 \%$.

For simulating the influence of steel bar reinforcement, that is usually present at the top of slab, on the strength of contact, the specimen was pre-compressed by horizontal forces restraining transverse strains of concrete, perpendicular to the rib of profiled steel sheeting. The contact shear strength increased when specimens were pre-compressed by horizontal forces. Due to the action of horizontal force of $1 \mathrm{kN}\left(\sim 0,05 F_{u 0}\right)$ average shear strengths of contact increased by $10 \%$. When horizontal pre-compression forces increased to $3 \mathrm{kN}\left(\sim 0,16 F_{u 0}\right)$ contact shear strength increased by $25 \%$ and the increases to $5 \mathrm{kN}\left(\sim 0,27 F_{u 0}\right)$ resulted in strength increase of $28 \%$ (Fig 5).

Nature of failure of specimens is shown in Fig 6. The crack in this figure shows that ribs of steel sheeting influence transversal and vertical deformations of concrete.
Ribs of steel sheeting frequently cut the edge of concrete keys or draw out concrete (Fig 6).
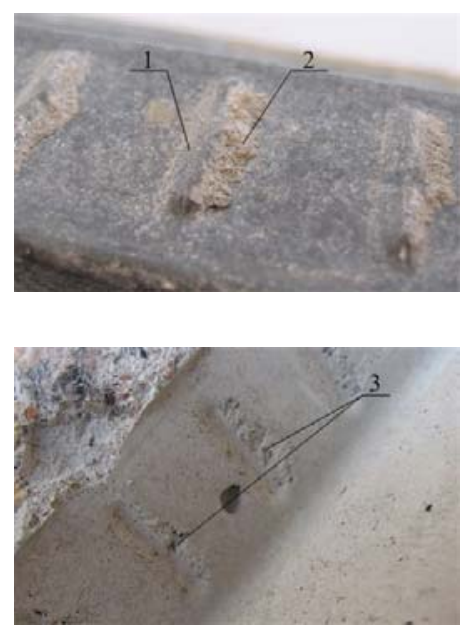

Fig 6. Nature of cutting of edge concrete keys: 1 - ribs of sheeting; 2 - edge of concrete keys; 3 - draw out edge of concrete keys

\section{Analysis of behaviour of contact}

The a analysis of contact between steel profiled sheeting and concrete behaviour revealed that the layers slip in relation to each other when concrete keys at the top of the rib are crushed (Fig 6) or transverse ribs of steel sheeting are deformed.

Under the action of shear force only the greatest deformation of the contact is obtained when there is no precompression (Fig 7). But it was determined that these deformations increased lineally up to the contact failure. According to diagrams (Fig 7), an initial rate of deformations increase is greater. When pre-compression force is $\approx 0,4 F_{u}$, the growth of deformations slows down. As the maximum shear force was reached, increases in shear deformations become unstoppable, indicating that the keys in the contact were cut or concrete above the rib was crushed or split.

Shear strain in steel-concrete contact subjected to shear force was reduced by pre-compression of this contact with perpendicular forces (Figs 7, 8). At $F_{p c}=5 \mathrm{kN}$ $\left(\sim 0,28 F_{u 0}\right)$ contact shear strain value less than $\sim 25 \%$ was obtained in comparison with that of non pre-compressed. But this difference in strain values reduced with shear force and in the stage of incipient contact failure the strain was similar to that of contact without precompression.

Strain restraint in the contact was caused by frictional resistance in contact and by increases in effective cutting areas of concrete keys at transverse ribs in steel (effect of key pre-compression). In the case of non precompressed contact steel sheeting at the key can move up and it will result in reduced cutting (splitting) concrete area at the key. These are pointed out too in investigations [19, 22]. Actions of pre-compression forces result in increases of cutting and splitting areas of the key and a greater shear force is required to cut. 
a

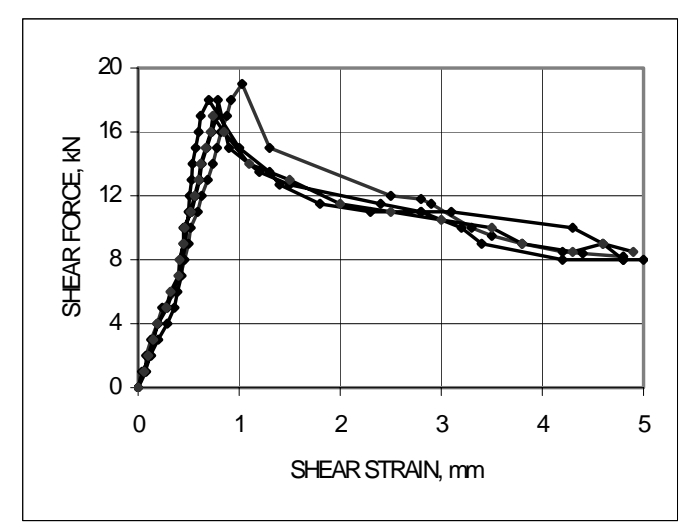

b

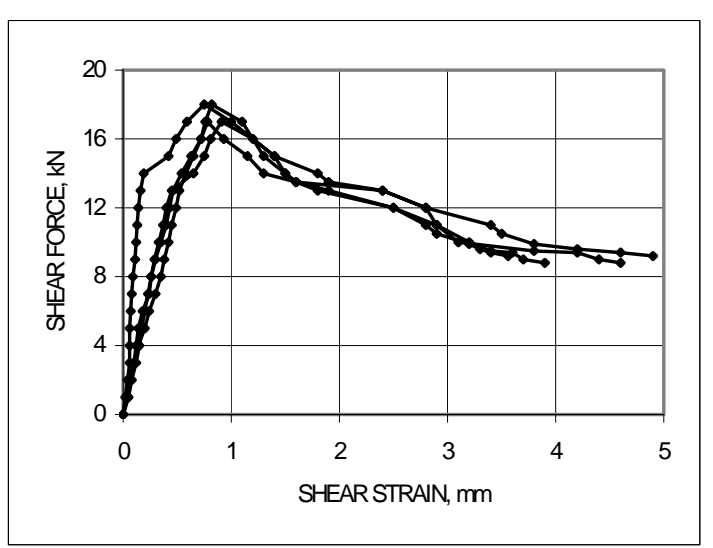

Fig 7. Relationship between shear strain and shear force for contact: a - without pre-compression force $\left(F_{p c}\right)$; $\mathrm{b}-$ with $F_{p c}=5 \mathrm{kN}$

Test results revealed that for specimens precompressed by vertical force (CB, CD, $\mathrm{CE}$ ) at the ultimate (failure) shear force $\left(F_{u}\right)$ contact shear strains in all series of specimens were almost of the same value. It can be explained by consideration that a contact failure occurred with the damage of all ties. Key sheared horizontal movement of the sheeting in respect to the concrete has to be of the same value regardless of contact surface pre-compression force value. This is established by experiments.

When a transverse strain of the specimen was restrained by horizontal pre-compression force, the deformability of contact decreased. Moreover, failure of contact was plastic (Fig 9). At the maximum shear force sufficiently large shear deformations occurred, which in $F_{u}$ graph are shown by a horizontal line. When failure without horizontal pre-compression was sudden, the horizontal pre-compression of specimens and restraining of transverse strains resulted in a substantially more plastic failure. Character of failure for all specimens of series $\mathrm{CF}$, CG, CH pre-compressed by horizontal force was very similar.

\section{Analytical evaluation of contact deformability in design of composite slabs}

The analysis performed by us and investigations into composite structures made by many other authors $[1,4$, $10,13,14,23$ ] showed that the contact between the layers a

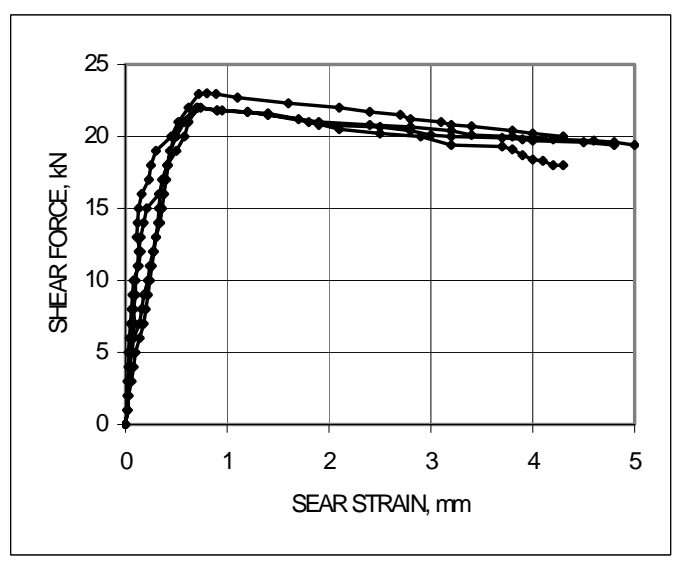

b

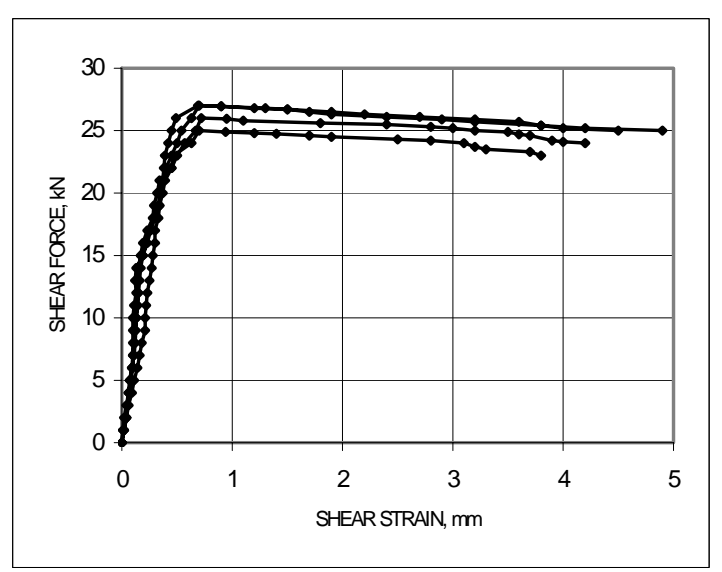

Fig 8. Relationship between shear strain and shear force for contact: a - with pre-compression force $F_{p c}=10 \mathrm{kN}$; $\mathrm{b}-F_{p c}=15 \mathrm{kN}$

in all stages of their behaviour is not absolutely stiff. Thus, it is necessary to take into account partial stiffness of the contact in calculations of strength and deformations of such structures. Investigations in deformations of the contact between the concrete and the steel profiled sheeting (Figs 7-9) confirmed our theoretical assumptions that three stages in behaviour of the contact can be distinguished. In the first stage the contact behaviour is elastic. In this stage adhesion and the keys provide a common action of the concrete and the profiled sheeting. The investigations performed indicated that in this stage the adhesion can in some cases be damaged. The horizontal displacement of the layers in relation to each other is due to elastic strains of the concrete and steel sheeting.

The local compression of the keys in the contact begins with an increase of tangential stress. The contact proceeds to the second stage. In this stage displacement of the layers in relation to each other increases substantially (Figs 7-9). Spatial state of stresses appears in the contact zone as shown in Fig 1 b. The shear force acting in the contact results in shear and local compression actions on the keys in the contact. Shear stiffness of the keys is sufficient and there is a possibility for the keys to be broken due to local compression. Due to such a compression the layers are separated from each other. Since the sheeting rib is of dovetail shape this displacement 
(perpendicular to the direction of shear force) is restrained. Still due to plastic deformations at the rib corners (Fig 2) reduces this restraint and displacement of the layers in relation to each other begins to increase significantly. Further increase in displacement of the layers in relation to each other proceeds with increase in acting shear force.

Behaviour of the contact switches to the third stage when the main resisting force is friction. In this stage of behaviour tensile stresses in the concrete increase further. Now stresses acting in the contact are reduced and displacement between the layers increases substantially.

a

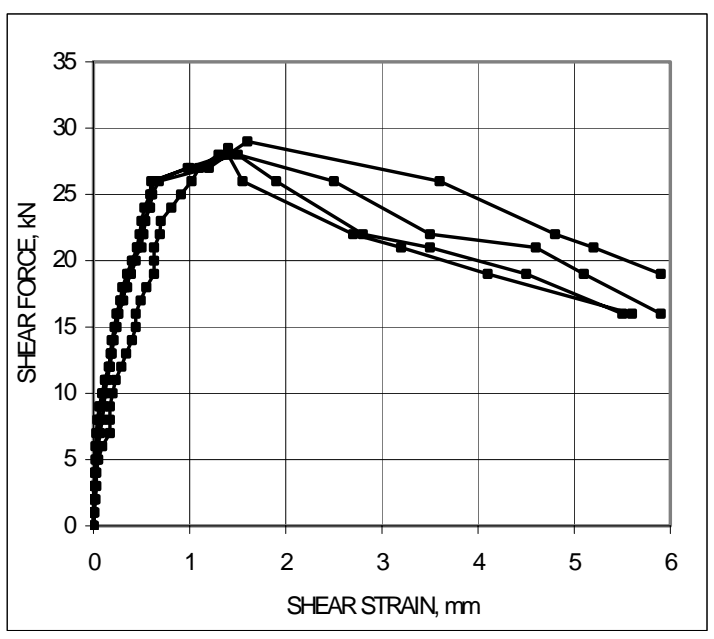

b

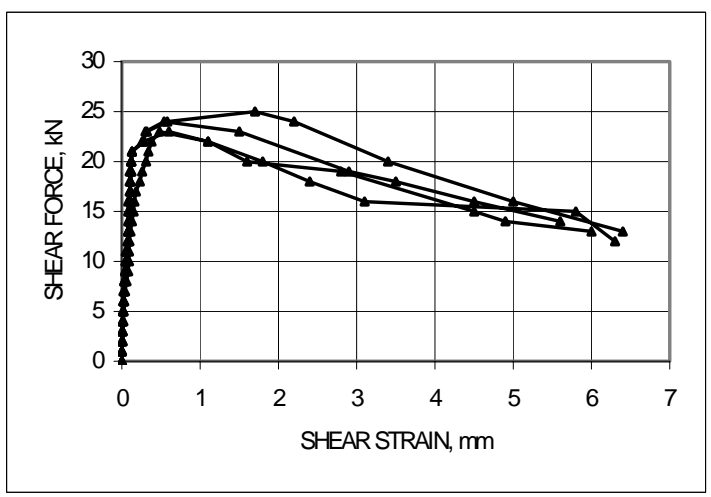

C

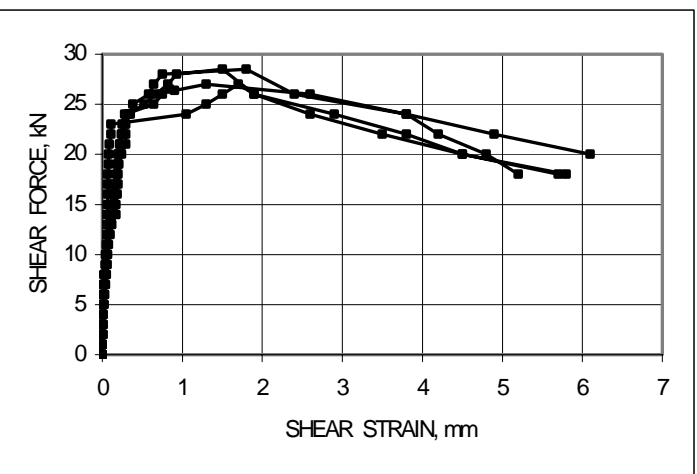

Fig 9. Relationship between contact shear strains and shear force, when transverse strain restraining force $F_{h}$ : $\mathrm{a}-F_{h}=1 \mathrm{kN} ; \mathrm{b}-F_{h}=3 \mathrm{kN} ; \mathrm{c}-F_{h}=5 \mathrm{kN}$

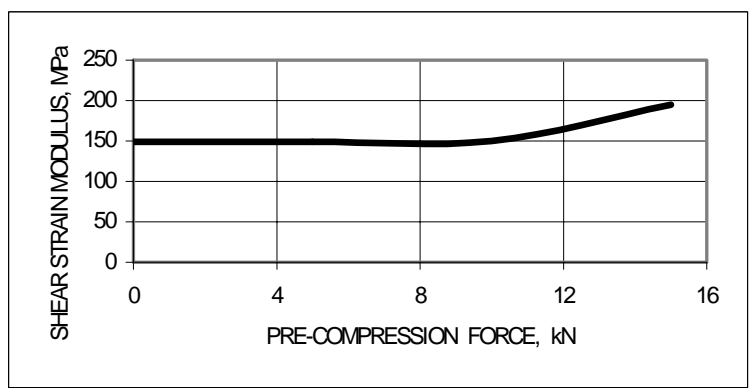

Fig 10. Influence of vertical pre-compression force on shear strain modulus $\left(G_{w}\right)$

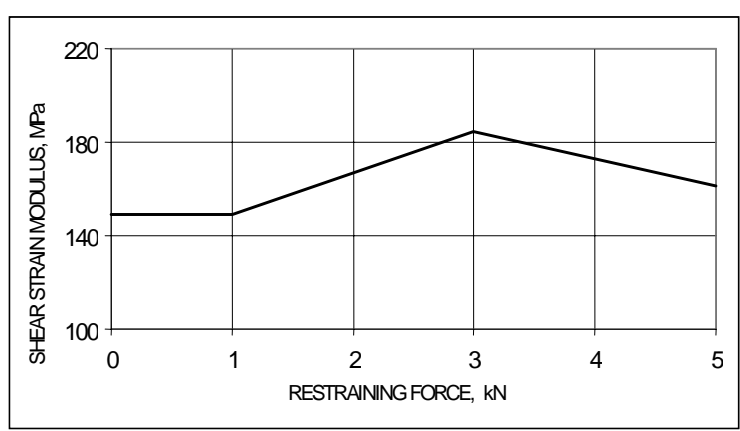

Fig 11. Influence of horizontal pre-compression force on shear strain modulus $\left(G_{w}\right)$

Since the contact behaviour depends on the shape of the keys in the profiled sheeting and strength of the concrete, then one of the means to increase the contact strength is the contact pre-compression. Strength of the contact increases due to action of pre-compressing force of direction coinciding with the direction of tensile stresses and deformations due to the stresses of the same value are reduced (Fig 5).

The performed analysis of shear strains development in the contact between concrete and the profiled sheeting showed that the contact stiffness can be assessed by the shear strain modulus $G_{w}$. This value depends on the behaviour for the contact and on forces restraining deformations in the contact (Figs 10,11).

\section{Conclusions}

Analysis of stress state in composite structures allows distinguishing three stages in behaviour of the contact between metal profiled sheeting and the concrete: elastic, plastic deformation and formation of cracks.

In composite structures the strength of contact between profiled steel sheeting and concrete depends on contact pre-compression force value. Pre-compression force up to $\sim 0,27 F_{u 0}\left(F_{u 0}-\right.$ ultimate (failure) shear load of contact without pre-compression) has an insignificant effect on contact strength; it is of the same value as that of non pre-compressed contact. A pre-compression force of $\sim 0,55 F_{u 0}$ finds contact strength increases by $22-25 \%$. Pre-compression force of $0,8 F_{u 0}$ increases the contact strength by $\sim 50 \%$.

Frictional forces increase and the pre-compression effect of keys comes into play with contact precompression force. Resulting in increases of shear area of 
shear keys, at the same time contact stiffness is increased. Though shear strains in contact at failure are independent of contact pre-compression value, in other stages of contact service these strains depend on contact precompression force. Slips of layers in relation to each other, subjected to shear force of the same value, are reduced with an increase of contact pre-compression force.

Contact strength increases due to restraint of concrete strains developing transvers to the ribs of profiled sheeting. Action of force of $\sim 0,16 F_{u 0}$ results in increases of contact shear strength by $25 \%$. When horizontal forces restrain concrete transverse strains, contact failure is substantially more plastic and less hazardous.

The performed analysis in development of shear strains in the contact between concrete and the profiled sheeting of the composite structures showed that the contact stiffness may be assessed by the shear strain modulus $G_{w}$ of the contact. This value depends on the stage of the contact behaviour and on forces restraining deformations there.

\section{References}

1. Marčiukaitis, G.; Valivonis, J. and Vaškevičius, A. Analysis of behavior of composite elements with corrugated steel sheet. Statyba (Civil Engineering), VII(6), 2001, p. 425-532 (in Lithuanian).

2. Burnet, M. J. and Oehlers, D. J. Rib shear connectors in composite profiled slabs. Journal of Constructional Steel Research, 57(12), 2001, p. 1267-1287.

3. Yaping, Wu; Ynanlin, Z.; Ynanming, L. and Weideng, P. Analysis of shear log and shear deformation effects in laminated composite box beams under bending loads. Composite Structures, 55(2), 2002, p. 147-156.

4. Velykovic, M. An improved partial connection method for composite slab design. In: Proc of Engineering Foundation Conference Composite Construction in Steel and Concrete III. Irsee, Germany, June 9-14, 1996. Ed. by C. D. Buckner and B. M. Shohrooz, 1996, p. 644-659.

5. Essawy, I. Bond in thin gauge steel concrete composite structures. In: Proc of Engineering Foundation Conference Composite Construction in Steel and Concrete II. Trout Lodge, Potosi, Missouri, 14-19 June, 1992. Ed. by W. S. Easterling and W. M. K. Roddis, 1992, p. 630-643.

6. Wright, H. D. and Essawy, M. I. Bond in thin gauge steel concrete composite structures. In: Proc of Engineering Foundation Conference Composite Construction in Steel and Concrete III. Irsee, Germany, June 9-14, 1996. Ed. by C. D. Buckner and B. M. Shohrooz, 1996, p. 630-643.

7. Schuurman, R. G. and Stark, J. W. B. Longitudinal shear resistance of composite slabs. In: Proc of Engineering Foundation Conference Composite Construction in Steel and Concrete III. Irsee, Germany, June 9-14, 1996. Ed. by C. D. Buckner and B. M. Shohrooz, 1996, p. 89-103.

8. Crisinel, M. and O’Leary, D. Composite floor slab design and construction. Structural Engineering International, 6(1), 1996, p. 41-46.
9. Johnson, R. P. and Yuan, H. Shear resistance of stud connectors with profiled sheeting. In: Proc of International Conference Composite Construction - Conventional and Innovative, Innsbruck, Austria, 16-18 Sept 1997. 9 p.

10. Bode, H.; Minas, F. and Sauerborn, I. Partial connection design of composite slabs. Structural Engineering International, 6(1), 1996, p. 53-56.

11. Stark, J. W. B. and Brekelmans, J. W. P. M. Plastic design of continuous composite slabs. Structural Engineering International, 6(1), 1996, p. 47-53.

12. EN 1994-1-1:2004E. Eurocode 4: Design of composite steel and concrete structures - Part 1-1: General rules and rules for buildings. European Committee for Standardization, 2004.

13. Crisinel, M. and Marimon, F. A new simplified method for the design of composite slabs. Journal of Constructional Steel Research, 60(3-5), 2004, p. 481-491.

14. Wang, Y. C. Deflection of steel-concrete composite beams with partial shear interaction. Journal of Structural Engineering, 124(10), 1998, p. 1159-1164.

15. Motak, J. and Machacek, J. Experimental behaviour of composite girders with steel undulating web and thin-walled shear connector's hilti stripcon. Journal of Civil Engineering and Management, X(1), 2004, p. 45-49.

16. Bode, H. and Sauerborn, I. Modern design concept for composite slabs with ductile behaviour. In: Proc of an Engineering Foundation Conference Composite Construction in Steel and Concrete II. Trout Lodge, Potosi, Missouri, 14-19 June, 1992. Ed. by W. S. Easterling and W. M. K. Roddis, 1992, p. 125-141.

17. Chajes, M. J.; Finch, W. W.; Januszka, T. F. and Thomson, T. A. Bond and force transfer of composite material plates bonded to concrete. ACI Structural Journal, 96(2), 1996, p. 208-217.

18. Chen, J. F. and Teng, J. G. Anchorage strength models for FRP and steel plates bonded to concrete. Journal of Structural Engineering, 127(7), 2001, p. 784-791.

19. Rondal, J. and Moutafidou, A. Study of shear bond in steel composite slabs. In: Proc of International Conference Composite Construction - Conventional and Innovative. International Conference, Innsbruck, Austria, 16-18 Sept 1997. $11 \mathrm{p}$.

20. Valivonis, J. and Popov, V. Bond of nonmetallic exterior asbestos - cement sheets in reinforced concrete beams under bending. In: Proc of International Conference Bond in Concrete. Riga, Latvia, 15-17 Oct 1992, p. 8-8 - 8-16.

21. Tenhovuori, A.; Karkkainen, K. and Kanerva, P. Parameters and definitions for classifying the behaviour of composite slabs. In: Proc of Engineering Foundation Conference Composite Construction in Steel and Concrete III, Irsee, Germany, June 9-14, 1996. Ed. by C. D. Buckner and B. M. Shohrooz, 1996, p. 752-765.

22. Cholmianskij, M. M. Concrete and reinforced concrete: deformations and strength. Moscow, 1997. 569 p. (in Russian).

23. Ching, Au. and Buyukozturk, O. Debonding of FRP plated concrete: A tri-layer fracture treatment. Engineering Fracture Mechanics, 73(3), 2006, p. 348-365. 


\section{PLIENINIO PROFILIUOTOJO LAKŠTO IR BETONO KONTAKTO STANDUMO IৃTAKA KOMPOZITINIŲ KONSTRUKCIJŲ ELGSENAI}

\section{J. Valivonis}

\section{Santrauka}

Skaičiuojant sluoksniuotąsias konstrukcijas, būtina tikrinti pjūvius: statmenaji, istrižaji ir horizontaluji. Kompozitiniu plieninių ir betoninių konstrukcijų su išorine profiliuotaja armatūra kontakto deformatyviškumas ir stiprumas turi tiesioginę ittaką konstrukciju elgsenai. Betono ir plieninio profiliuotojo lakšto kontakto elgsenoje išskiriamos trys stadijos: pirmoji - kol nepažeistas cheminis sukibimas, antroji - pažeidus chemini sukibimą, trečioji - pažeidus mechanini sukibimą kai bendrą elgseną užtikrina trintis ir inkarai.

Kontakto deformatyviškumui ir stiprumui didelę ittaką turi profiliuotojo lakšto forma ir kontakto apspaudimo jèga. Eksperimentinių tyrimų metu bandinių kontaktas buvo apspaustas kontakto plokštumai statmena jèga. Tyrimais nustatyta, kad, didejjant kontakto apspaudimo jégos dydžiui, kontakto tarp betono ir plieninio profiliuotojo lakšto stipris didejja. Veikiant apspaudžiančiajai jègai, kontakto šlyties deformacija mažèja.

Reikšminiai žodžiai: profiliuotasis plieninis lakštas, betonas, jungtis, stipris, slydimas.

Juozas VALIVONIS. Doctor, Associate Professor. Dept of Reinforced Concrete and Masonry Structures. Vilnius Gediminas Technical University (VGTU), Sauletekio al. 11, LT-10223 Vilnius, Lithuania. Doctor (1986). Author of over 50 publications. Research interests: theory of reinforced concrete behaviour, composite structures, reinforced concrete bridges. 